\title{
Innovative Overheating solution for solar thermal collector using a reflective surface included in the air gap
}

\author{
A. AMICHE ${ }^{1, *}$, S. M. K. EL HASSAR ${ }^{2}$, A. LARABI ${ }^{3}$, Z.A. KHAN $^{4}$, Z. KHAN ${ }^{5}$, F. J. \\ AGUILAR $^{6}$, P. V. QUILES ${ }^{7}$
}

\begin{abstract}
${ }^{1}$ Ph.D. Researcher Corresponding author. University of Sciences \& Technology Houari Boumediene (USTHB). Faculty of Civil Engineering. Laboratory of Build Environment (LBE). Email: aamiche@usthb.dz. Adresse: USTHB, FGC, BP 32 EL ALIA 16111 BAB EZZOUAR ALGIERS, ALGERIA.
\end{abstract}

${ }^{2}$ Lecturer, USTHB, Faculty of Civil Engineering, Laboratory of Build Environment (LBE).

${ }^{3}$ Professor, USTHB, Faculty of Electronics and Computer Science, Laboratory of Electrics \& Industrials Systems (LSEI).

${ }^{4}$ Professor, Bournemouth University, Faculty of Science and Technology, NanoCorr, Energy and Modelling (NCEM) Research Group, Fern Barrow, Talbot Campus, Poole, Dorset BH12 5BB, UK.

${ }^{5} \mathrm{PhD}$, Bournemouth University, Faculty of Science and Technology, NanoCorr, Energy and Modelling (NCEM) Research Group, Fern Barrow, Talbot Campus, Poole, Dorset BH12 5BB, UK.

${ }^{6} \mathrm{PhD}$, University Miguel Hernández, Avda. Universidad S/N, Elche 03202, Spain.

${ }^{7}$ Professor, University Miguel Hernández, Avda. Universidad S/N, Elche 03202, Spain.

\begin{abstract}
In this work, a new solution to prevent the overheating of solar collectors in the case of stagnation is presented. The solution proposed consists of inserting a reflective sheet inside the solar collector between the absorber and the glass cover to reduce the incoming energy by reflecting solar radiation. This protection is switched ON or OFF according to the absorber temperature. A prototype has been manufactured and tested in outside conditions and in laboratory. A numerical model of the solar collector with the protection was developed and has been validated. The calculated temperature values are very close to the measured data. The experimental and numerical results showed the good behaviour of the proposed solution.
\end{abstract} Modelling

Keywords: Flat plate solar collector; Stagnation; Shading protection; Experimentations;

* Corresponding author. Tel.: +216 664151 442; E-mail addresses: amiche588 @ hotmail.fr. 


\section{Nomenclature}

\section{$\underline{\text { Capital letters }}$}

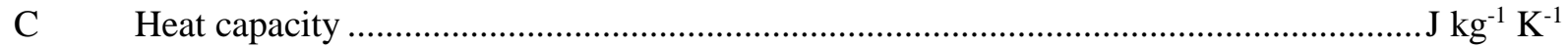

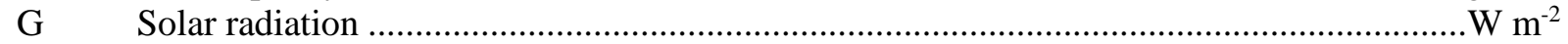

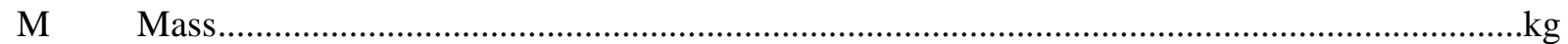

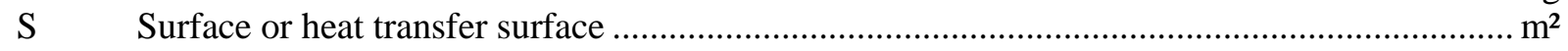

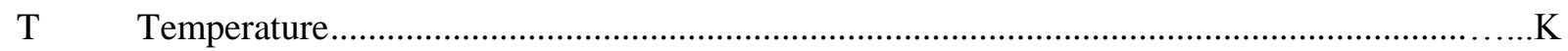

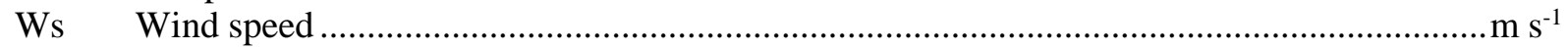

\section{$\underline{\text { Small letters }}$}

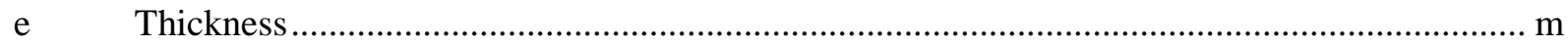

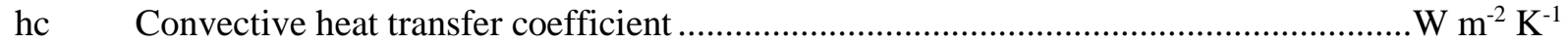

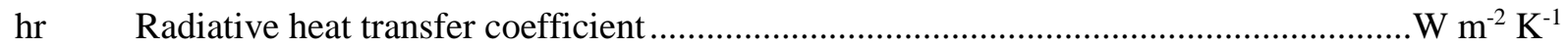

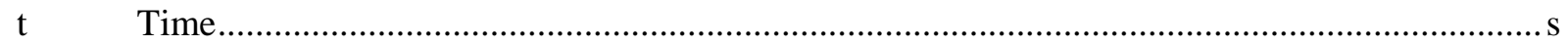

\section{Greek Symbols}

\begin{tabular}{|c|c|}
\hline$\alpha$ & Absorbance \\
\hline$\varepsilon$ & $(-)$ \\
\hline$\lambda$ & Thermal conductivity \\
\hline$\rho$ & Density \\
\hline$\tau$ & 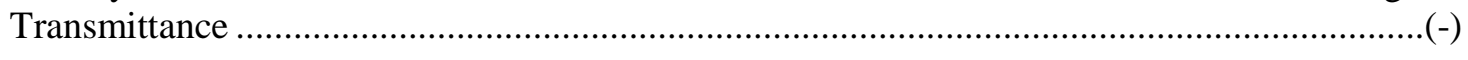 \\
\hline
\end{tabular}

\section{$\underline{\text { Indices }}$}

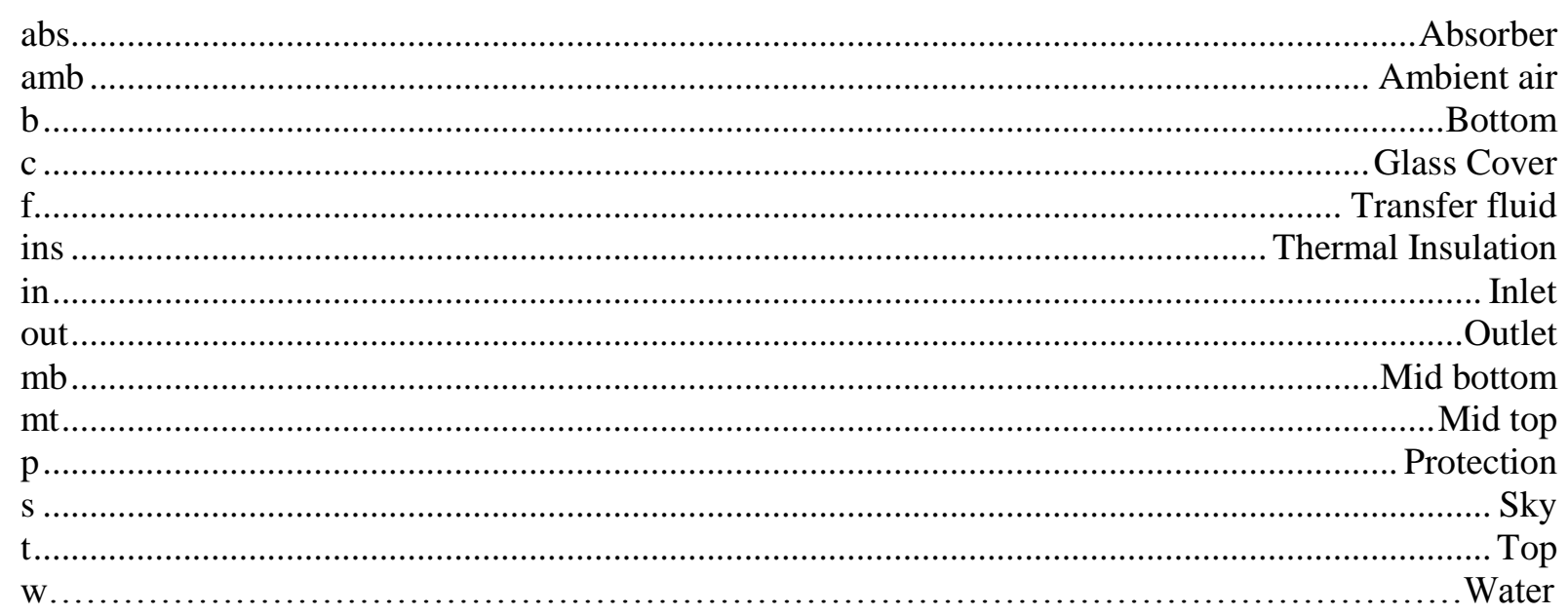




\section{Introduction}

Natural gas is the main energy source in the building sector in Algeria. The use of solar energy in this country, an abundant renewable energy source, is currently very low. In order to reduce the fossil fuels consumption, a law promulgated in 1999 focuses mainly on thermal insulation of the building envelope, greater use of efficient equipment and more frequent use of solar systems. The promotion of the solar systems is now a priority in Algeria, particularly for sanitary hot water production [1].

Different types of solar collectors are available such as flat plate solar collectors, vacuum tube solar collectors and concentrating solar collectors. Many improvements have been developed since the first collector was produced [2,3]. In most cases, the innovations are aimed to reduce the heat losses of the solar collectors predisposing them to overheating problem [4, 5]. It should be noted that the selective surface coating increases overheating temperatures which can reach $200^{\circ} \mathrm{C}$. Overheating occurs when the fluid flow is interrupted (e.g. power cut, failure of the primary pump). Without protection against overheating, vapour is produced and the installation components may be damaged. The standard solar fluid is a mix of propylene glycol and water. Overheating causes glycol to degrade and the mix of propylene glycol and water becomes acidic. This process accelerates scaling and causes premature component degradation [6].

To solve overheating problem, several approaches exist. The solutions applied directly to the solar collector have the advantage to solve the problem at the source [6]. The use of special coatings applied on the absorber plate and/or on the glass allows to modify their optical properties depending on their temperature [7, 8 and 9]. Another option is to include a heat waster at the back of the solar collector [6]. The use of a ventilation system added to the solar collector allows the rejecting of the excess energy [10, 11 and 12]. The characteristics of the stagnation depend also of the design of the primary circuit. The relative position between the expansion tank and the non return valve is extremely important and should be considered [13]. Finally, the shading of the solar collectors, which can be manual or automated, is a conventional solution against overheating.

This work focuses on the study of grid liquid flat-plate solar collectors in stagnation conditions. We studied the thermal behaviour of a glazed solar thermal collector equipped with an added shading system. The system is a new approach and consists of a reflective protection mounted between the absorber plate and the glass cover. The experimental study was conducted in both laboratory and field conditions. The thermal behaviour of this system has been numerically modelled. Predictions of the numerical model were compared with experimental data for its validation. This report presents some results of this work.

\section{Solution overview}

The proposed solution consists of inserting a reflective sheet, in case of stagnation, between the absorber plate and the glass cover. The solar radiation is reflected before reaching the absorber plate. The energy transmitted to the circulating fluid is highly reduced and its temperature is significantly lowered. Being inside the solar collector, the reflective sheet is protected against the climatic hazards (wind, hail). A schematic section of our system can be seen in Fig. 1. 
1- Absorber

2- protection

3- Glass Cover

4- Opening

5-Box

6-Rolled Protection

7- Rotation Axis

8- Insulation

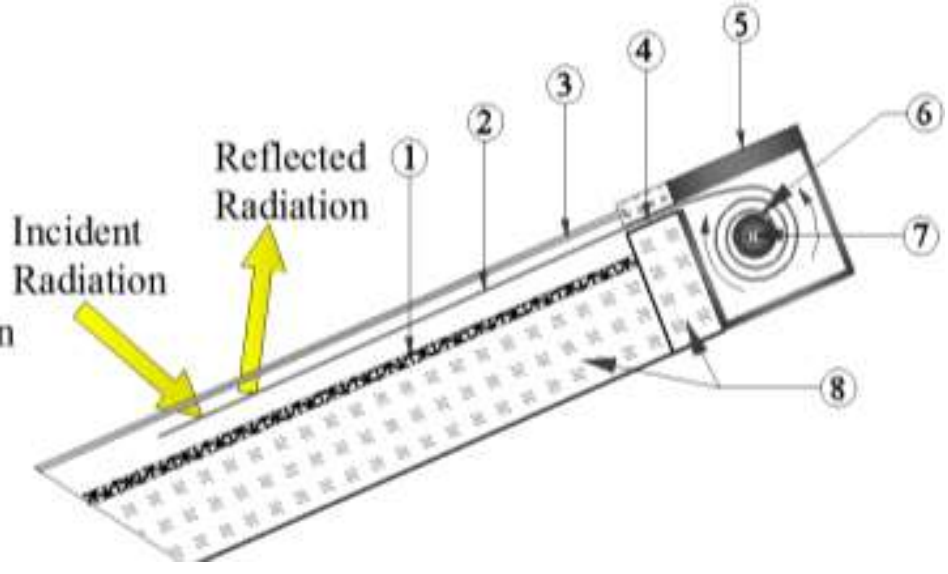

Fig.1. Schematic of the proposed system.

The reflective protection is wrapped around a rotation axis at the top of the solar collector in a special box. The chosen material for the protection is a silver aluminium mirror film. This material has a high reflectivity, low emissivity and a good flexibility. In addition, this material is highly resistant to high temperatures. Its reflection coefficient is equal to 0.82 with an absorption coefficient equal to 0.18 and a thermal emissivity equal to 0.1 .

The proposed system has the following advantages: it can be adapted to a wide range of solar thermal collectors; it is lightweight which allows the installation of a low-powered rotating mechanism for winding and unwinding the aluminium sheet. In addition, the protection rate of the absorber area can be chosen.

\section{Outdoor tests}

\subsection{Presentation of the solar facility}

The outdoor tests were conducted on solar thermal experimental facility located at University of Miguel Hernandez (UMH), Elche city, Spain. The solar facility is installed on the laboratory building roof (see Fig. 2). It includes a solar collector, a pump, an expansion tank and an active heat sink. The solar collector is facing South and its tilt angle measured from the horizontal is equal to $45^{\circ}$. The heat transfer fluid used during the tests is water. The technical characteristics of the tested collector are presented in Table 1.

\section{Table 1}

Characteristics of the test outside collector

$\begin{array}{ll}\text { Glass cover } & \text { High resistant solar glass. } \\ & \text { Size }: 1000 \times 2040 \times 3.8(\mathrm{~mm})-\tau_{\mathrm{c}}=90.8 \% \\ & \mathrm{C}_{\mathrm{c}}=840 \mathrm{~J} \mathrm{~W}^{-1} \mathrm{~K}^{-1}-\rho_{\mathrm{c}}=2500 \mathrm{~kg} \mathrm{~m}^{-3}\end{array}$

Absorber

Copper absorber with a black selective coating.

9 tubes of $8 \mathrm{~mm}$ of inner diameter are welded on the back of the absorber.

Size : $950 \times 1900 \times 0,8(\mathrm{~mm})-\alpha_{\mathrm{abs}}=95 \%-\varepsilon_{\mathrm{abs}}=5 \%$

$\mathrm{C}_{\mathrm{abs}}=380 \mathrm{~J} \mathrm{~W}-1 \mathrm{~K}-1-\rho_{\mathrm{abs}}=8920 \mathrm{~kg} \mathrm{~m}^{-3}$

Insulation

Back thermal insulation: glass wool, thickness $=50 \mathrm{~mm}$. 


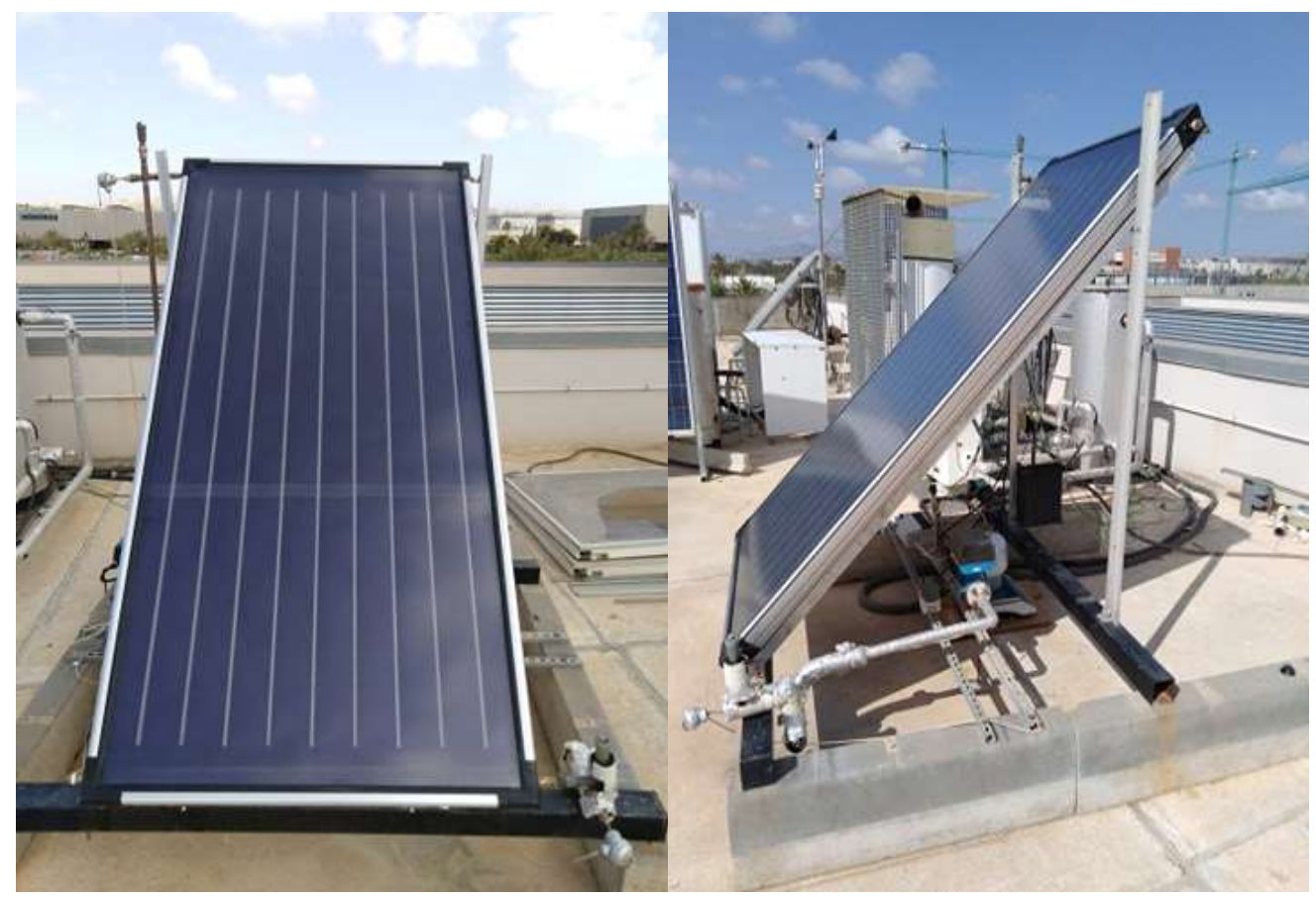

Fig.2. Solar testing facility.

For the tests, a prototype has been fabricated by modifying a commercial solar collector. The aluminium sheet introduced between the absorber and the glass cover has the following sizes: $850 \times$ $1900 \times 0.5 \mathrm{~mm}$. In the upper part of the solar collector frame, an opening was performed in order to introduce the protection. The reflective protection is wrapped around a metallic tube fixed behind the solar collector (see Fig. 3). Two small holes were performed in the lower part of the collector frame in order to allow the crossing of two wires attached to the aluminium sheet. These two wires are used for unwinding, manually, the aluminium sheet.

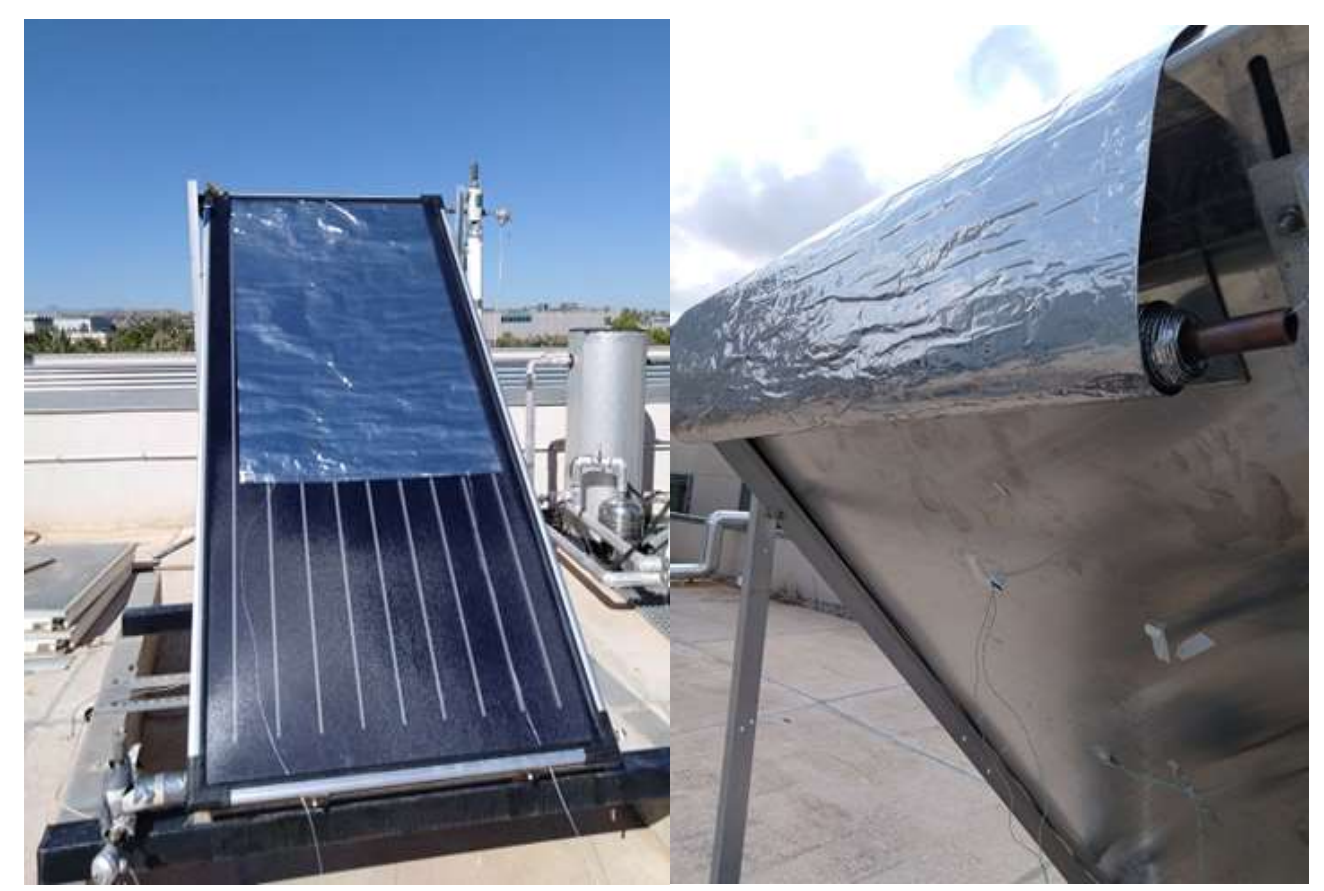

Fig. 3. Left: Prototype - Right: Protection mounted on axis. 


\subsection{Measured data}

The ambient temperature and relative humidity, the wind speed and direction and the solar radiation were measured using a meteorological station located very close to the experimental setup (see Fig. 4).

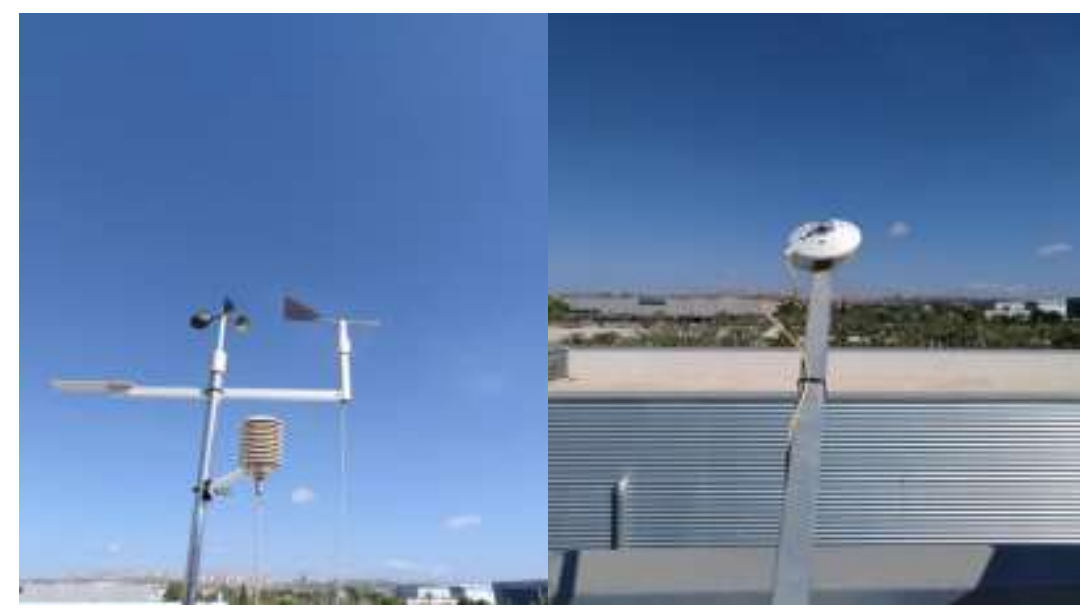

Fig.4. Left: Weather station - Right: Used pyranometer.

Water temperatures, at the bottom and at the top tubes of the solar collector, are measured using immersed type PT100 in 4-wire connection. The hydraulic circuit pressure was also measured.

The absorber temperature is measured using four K-type thermocouples connected along the rear face of the absorber. Four levels were defined: one thermocouple is located at the bottom of the collector, one at the top, one between the middle and the bottom and one between the middle and the top. This positioning allows the measurement of the temperature stratification in the absorber. The Fig. 5 shows the thermocouples positioning. In this figure, the thermocouples are called $\mathrm{T} 1$ to $\mathrm{T} 4$.

For reading the results, the following symbols are used: $\mathrm{T}_{\mathrm{abs}, \mathrm{t}}$ is the temperature obtained with the $\mathrm{T} 1$ thermocouple, $\mathrm{T}_{\mathrm{abs}, \mathrm{mt}}$ is the temperature obtained with the $\mathrm{T} 2$ thermocouple, $\mathrm{T}_{\mathrm{abs}, \mathrm{mb}}$ is the temperature obtained with the $\mathrm{T} 3$ thermocouple and $\mathrm{T}_{\mathrm{abs}, \mathrm{b}}$ is the temperature obtained with the $\mathrm{T} 4$ thermocouple.

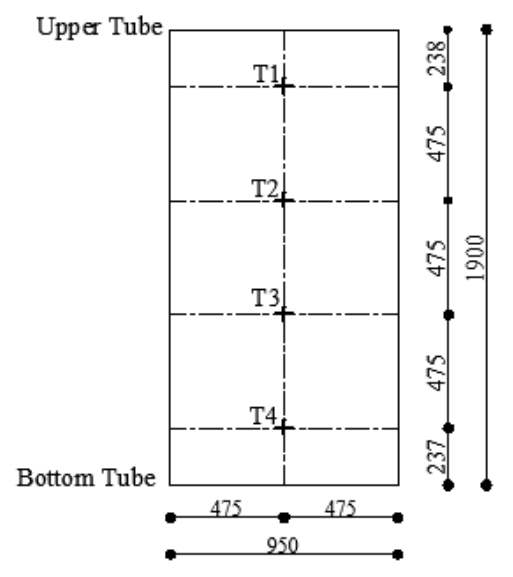

Fig.5. Thermocouples vertical positions on the absorber surface. 
The 34970A system data acquisition is used with the Agilent BenchLink data logger software. The data acquisition was carried out with a time step of 10 seconds. The accuracy of the measures is given in Table 2.

Table 2

Accuracy of the measurement

\begin{tabular}{lll}
\hline Measured Data & Measurement range & Accuracy \\
\hline Outside Air Temperature & $-20-80^{\circ} \mathrm{C}$ & $\pm 0.3^{\circ} \mathrm{C}$ \\
Relative Humidity of Outdoor Air & $0-100 \%$ & $\pm 2 \%$ \\
Wind Direction & $0-360^{\circ}$ & $\pm 3^{\circ}$ \\
Wind Speed & $0-50 \mathrm{~m} / \mathrm{s}$ & $\pm 2,5 \mathrm{~m} / \mathrm{s}$ \\
Solar Radiation & $0-1400 \mathrm{~W} / \mathrm{m}^{2}$ & $\pm 1 \%$ \\
Water temperature & $-200-600^{\circ} \mathrm{C}$ & $\pm 0.05^{\circ} \mathrm{C}$ \\
Absorber temperature & $-5-1100^{\circ} \mathrm{C}$ & $\pm 1.5^{\circ} \mathrm{C}$ \\
Circuit pressure & $0-6 \mathrm{bars}$ & $\pm 0.25 \%$ \\
\hline
\end{tabular}

\subsection{Prototype testing without protection}

In this test, the solar collector is not protected and the pump is shut down. Experimental measurements have been carried on October $6^{\text {th }}$. The results of the tests are shown in Fig. 6 (between 1:00 p.m. and 2:00 p.m.).
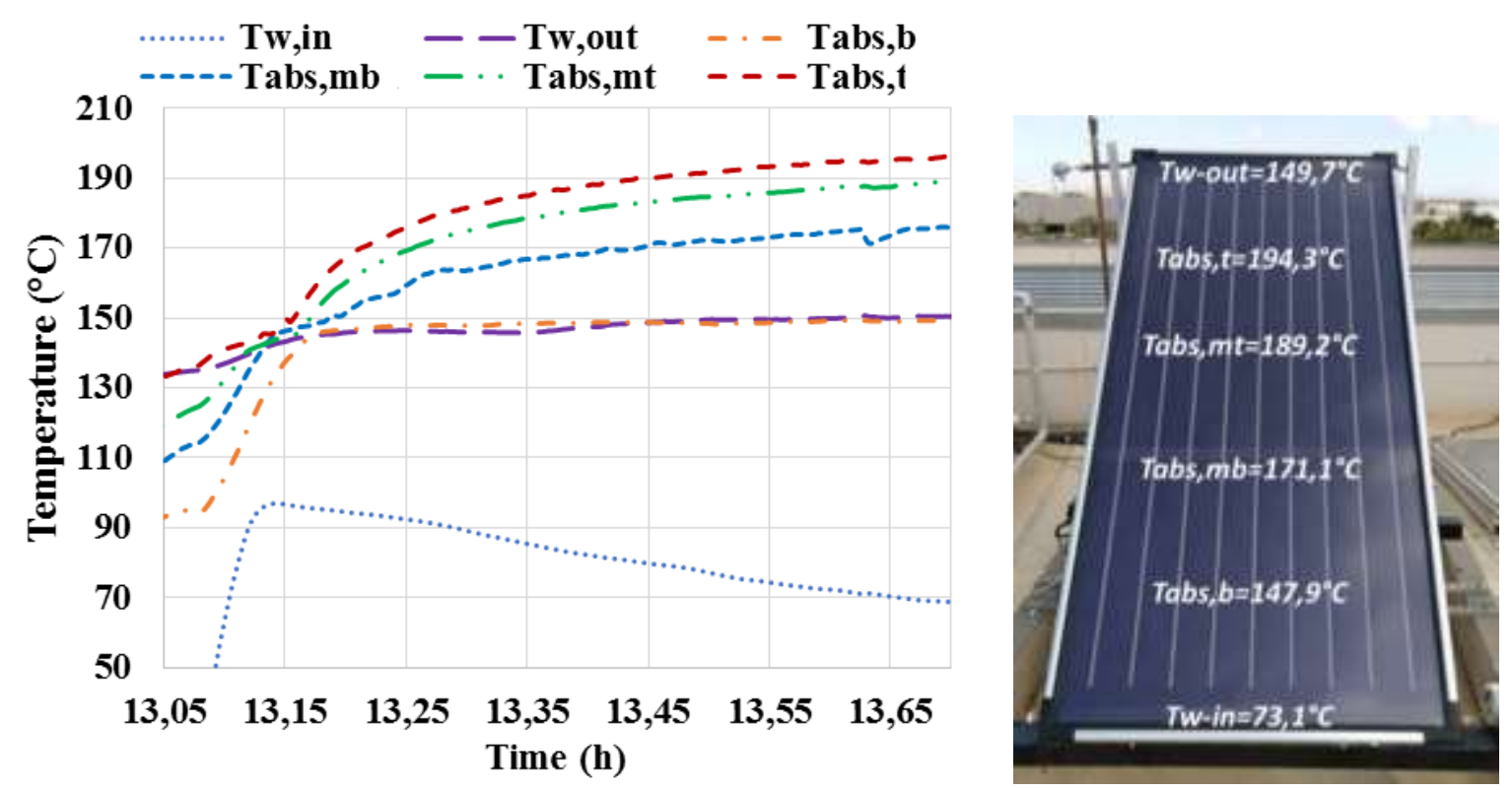

Fig.6. Temperatures variation of the tested collector without protection in case of stagnation - Left:

Test results between 1:00 p.m. and 2:00 p.m. - Right: Maximum temperatures obtained.

The solar radiation varies between 1000 and $1050 \mathrm{~W} / \mathrm{m}^{2}$. The water temperature at the upper collector $\mathrm{T}_{\mathrm{w}, \text { out }}$ approaches $150^{\circ} \mathrm{C}$ and the absorber temperature at the top $\mathrm{T}_{\mathrm{abs}, \mathrm{t}}$ exceeds $190^{\circ} \mathrm{C}$. The overheating is very important. 
Absolute initial pressure of the solar system was 3.48 bars; absolute pressure reaches 4.80 bars during overheating period. In these conditions, steam is produced on the solar collector (see Table 3).

\subsection{Prototype testing with continuous total protection}

In this case, the aluminium sheet completely covers the absorber. The measurements were performed on October $6^{\text {th }}$. The pump is stopped all the day (no water circulation). This schedule can occur during a system failure or during long periods of non-use of the solar facility (e.g., holidays). The test results are shown in Fig. 7.
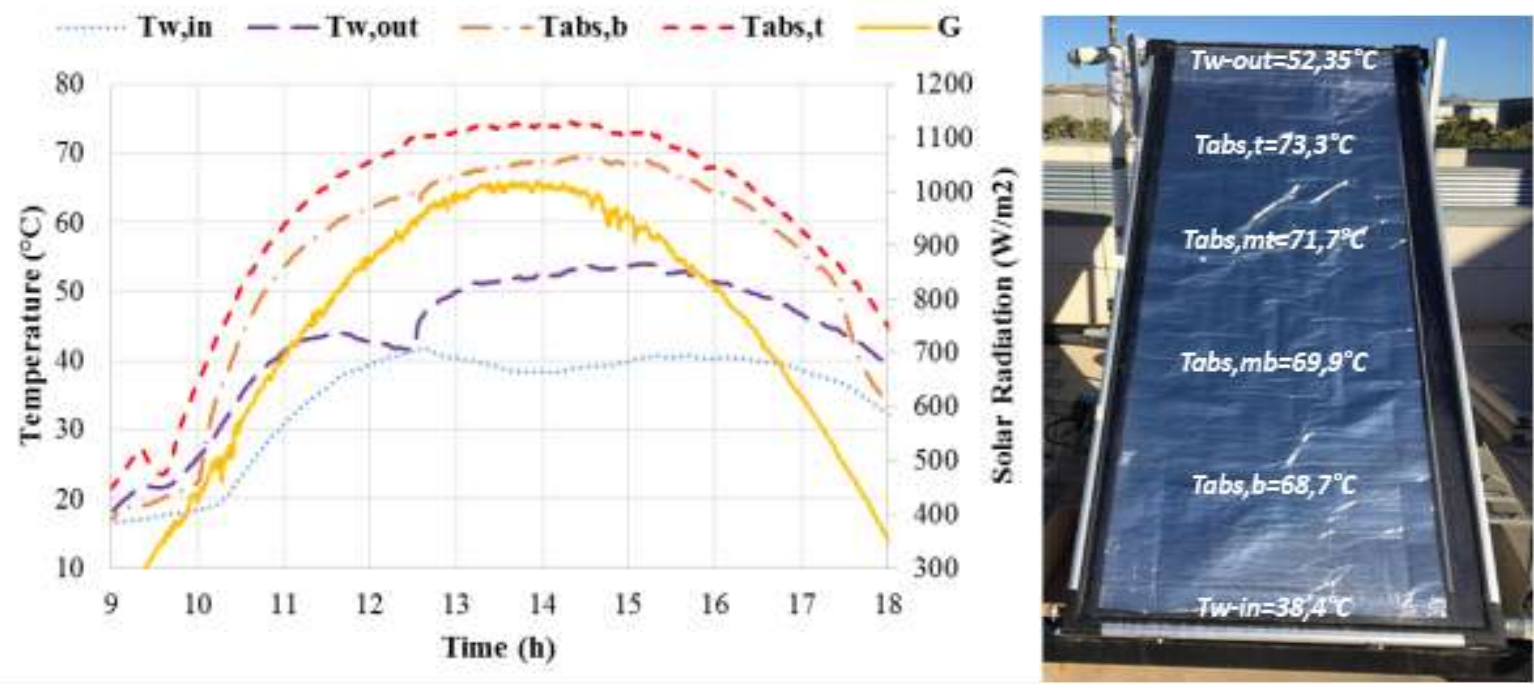

Fig.7. Temperatures variation of the tested collector with full protection in case of stagnation Left: Test results between 9:00 a.m. and 6:00 p.m. - Right: Test results at 2:00 p.m.

At the beginning of the test and for an incident solar radiation below $350 \mathrm{~W} / \mathrm{m}^{2}$, the water and absorber temperatures at the different positions of the solar collector are close to the ambient temperature $\left(21^{\circ} \mathrm{C}\right)$. Thereafter, at 2:30 p.m., the water temperature at the bottom collector $\mathrm{T}_{\mathrm{w}, \text { in }}$ reaches a maximum of $42^{\circ} \mathrm{C}$ and the water temperature at the upper collector $\mathrm{T}_{\mathrm{w}, \text { out }}$ approaches a maximum of $55^{\circ} \mathrm{C}$. This difference of $12^{\circ} \mathrm{C}$ is due to the stratification effect in the vertical tubes of the solar collector.

The absorber temperature and the solar radiation curves are highly correlated. When the value of the solar radiation exceeds $1000 \mathrm{~W} / \mathrm{m}^{2}$, the absorber temperature at the top $\mathrm{T}_{\mathrm{abs}, \mathrm{t}}$ reaches a maximum of $74^{\circ} \mathrm{C}$ and the absorber temperature at the bottom $\mathrm{T}_{\mathrm{abs}, \mathrm{b}}$ reaches $69^{\circ} \mathrm{C}$. For these temperatures, overheating is avoided. Thus, the absorber coating is protected against excessive temperatures and its physical and optical characteristics are preserved. Furthermore, there is no risk of steam production in the collector (see Table 3).

\subsection{Prototype testing with set point temperature}

The chosen schedule was as follows: at the beginning of the test, the pump was turned ON and the collector was unprotected. At 12:34, the pump was turned OFF and temperatures of the absorber and water increase quickly. When the water temperature at the collector upper tube $\mathrm{T}_{\mathrm{w} \text {,out }}$ reaches $120^{\circ} \mathrm{C}$, protection was activated for the rest of the day. This set temperature was chosen to eliminate any risk of 
steam production. The possibility to choose the set temperature gives great flexibility to our solution. The results of the test are shown in Fig. 8.

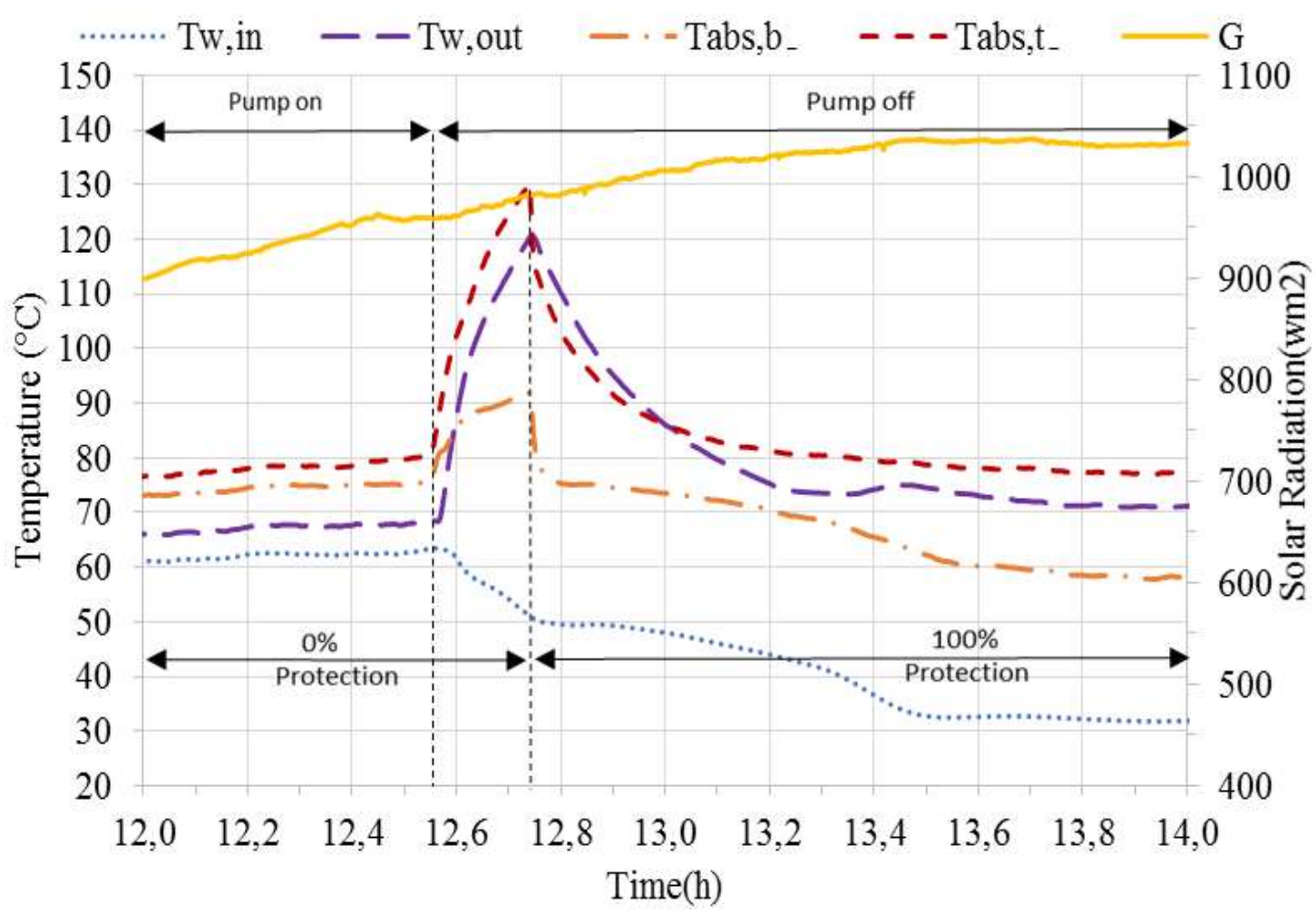

Fig.8. Temperatures measurements of the tested collector protected from a set temperature equal to $120^{\circ} \mathrm{C}$.

At the beginning of the test when the pump is switched ON, the water temperature and the absorber temperature increase slightly in accordance with the available solar radiation. The water temperature at the collector upper tube $\mathrm{T}_{\mathrm{w}, \text { out }}$ is $5^{\circ} \mathrm{C}$ higher than the temperature at the collector bottom tube $\mathrm{T}_{\mathrm{w}, \text { in. }}$

At 12:55, pump is switched OFF. The absorber temperature and the water temperature quickly increase. $\mathrm{T}_{\mathrm{w}, \text { out }}$ reaches $120^{\circ} \mathrm{C}$ and the absorber temperature at the top $\mathrm{T}_{\mathrm{abs}, \mathrm{t}}$ reaches $130^{\circ} \mathrm{C}$ in less than 13 minutes. It is noted that the temperature at the collector bottom tube $\mathrm{T}_{\mathrm{w} \text {,in }}$ decreases. This is due to the fact that the water contained in the cold pipes (return circuit) moves to the bottom of the solar collector to replace hot water moving up to the top of the solar collector.

When the temperature at the collector upper tube $\mathrm{T}_{\mathrm{w}, \text { out }}$ reaches $120^{\circ} \mathrm{C}$, the solar collector is fully protected. The absorber temperature at the top $\mathrm{T}_{\text {abs,t }}$ decreases from $130^{\circ} \mathrm{C}$ to $100^{\circ} \mathrm{C}$ in less than 10 minutes which corresponds to a decrease of $3^{\circ} \mathrm{C} / \mathrm{min}$. This temperature drop continues until thermal stabilization. After 17 minutes, the absorber temperature at the top $\mathrm{T}_{\text {abs,t }}$ stabilizes at $79^{\circ} \mathrm{C}$ and the absorber temperature at the bottom $\mathrm{T}_{\mathrm{abs}, \mathrm{b}}$ stabilizes at $59^{\circ} \mathrm{C}$. The water temperature at the collector upper tube $T_{w, \text { out }}$ stabilizes at $68^{\circ} \mathrm{C}$. Thus, after protection, the overheating is quickly stopped and the risk of steam production is eliminated (see Table 3 ). 


\subsection{Prototype testing with partial protection}

Tests with partial protection of the solar collector were carry out. Three percentages of protection, $75 \%, 50 \%, 25 \%$ were tested. It must be mentioned that in all the cases, the top of the solar collector has been protected, where temperatures are highest without protection (see Fig. 9).

The peak absorber temperature reached for each percentage of protection has been measured between 12:00 and 2:00 p.m. Test results are illustrated in Fig. 9. The tests conditions for each test are listed as follow:

- Collector $75 \%$ protected : solar radiation $\mathrm{G}=1007 \mathrm{~W} / \mathrm{m}^{2}$; wind speed $\mathrm{Ws}=2,4 \mathrm{~m} / \mathrm{s}$; ambient temperature $\mathrm{T}_{\mathrm{amb}}=25^{\circ} \mathrm{C}$;

- Collector $50 \%$ protected: solar radiation $\mathrm{G}=1010 \mathrm{~W} / \mathrm{m}^{2}$; wind speed $\mathrm{Ws}=1,4 \mathrm{~m} / \mathrm{s}$; ambient temperature $\mathrm{T}_{\mathrm{amb}}=26,4^{\circ} \mathrm{C}$;

- Collector $25 \%$ protected: solar radiation $\mathrm{G}=877 \mathrm{~W} / \mathrm{m}^{2}$; wind speed $\mathrm{Ws}=0,7 \mathrm{~m} / \mathrm{s}$; ambient temperature $\mathrm{T}_{\mathrm{amb}}=24,3^{\circ} \mathrm{C}$.

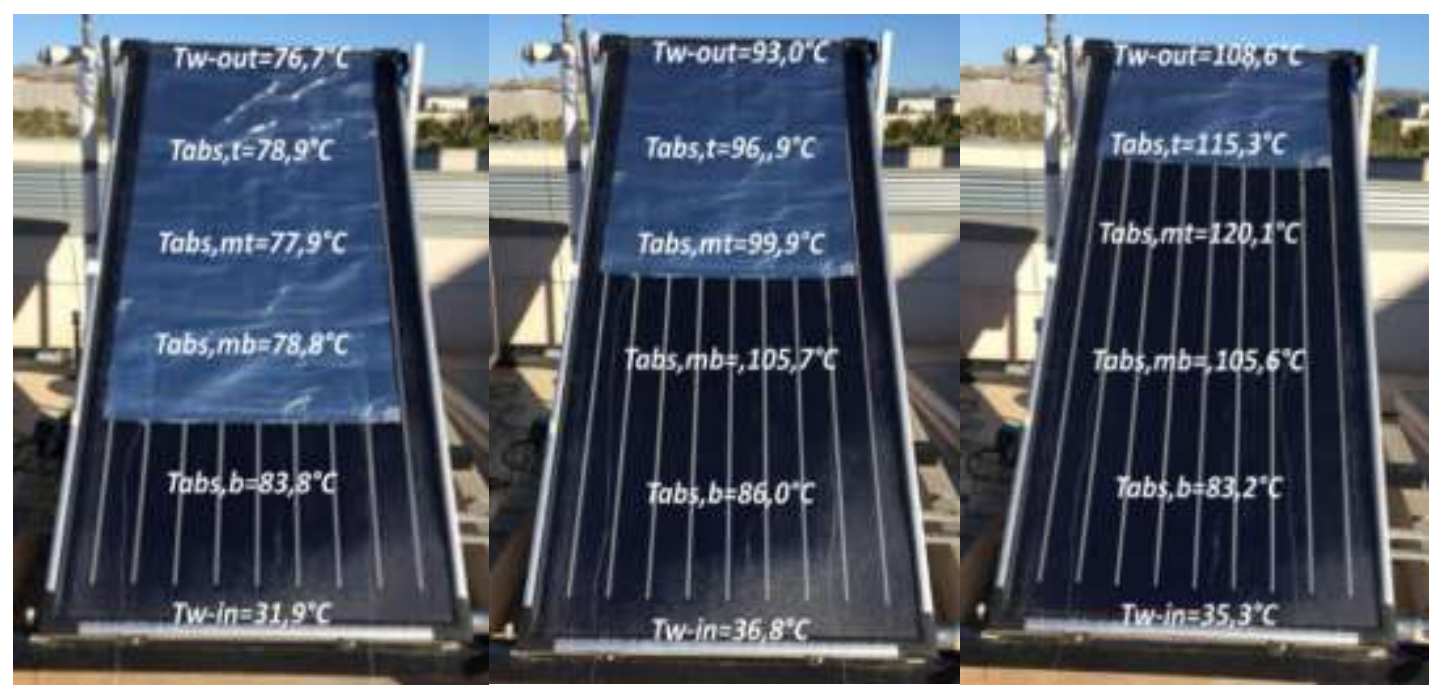

Fig. 9. Left to right tested collector with: $75 \%$ of protection - $50 \%$ of protection - $25 \%$ of protection.

The following observations are:

$>$ the absorber temperatures at the bottom $\mathrm{T}_{\mathrm{abs}, \mathrm{b}}$ measured for the three cases considered in partial protection are very close; they vary between 83 and $86^{\circ} \mathrm{C}$;

$>$ the absorber temperatures at the bottom middle $\mathrm{T}_{\mathrm{abs}, \mathrm{mb}}$ for the collectors $50 \%$ and $25 \%$ protected are almost equal and have the value of $105^{\circ} \mathrm{C}$;

$>$ the temperatures of the unprotected parts of the absorber are always higher than the protected parts of the absorber located above; thus, the stratification is not regular;

$>$ less we protect the absorber more the absorber temperature at the top middle $\mathrm{T}_{\mathrm{abs}, \mathrm{mt}}$ increases; it can reach $120^{\circ} \mathrm{C}$ in the case of a solar collector $25 \%$ protected.

These results show that from $50 \%$ of protection, it is possible to avoid easily overheating of the solar system. 


\subsection{Pressure results}

The table 3 shows the risk of steam production for each case considered. The absolute pressures measured in stagnation condition for $25 \%, 50 \%$ and $75 \%$ of protection are close to the initial absolute pressure. Without protection, the absolute pressure in the primary circuit increases by more than one bar and steam is produced.

\section{Table 3}

Absolute pressures measured

\begin{tabular}{ccccccc}
\hline $\begin{array}{c}\text { Percenta } \\
\text { ge of } \\
\text { protecti } \\
\text { on }\end{array}$ & $\begin{array}{c}\text { Absolut } \\
\text { e initial } \\
\text { pressure } \\
\text { (bar) }\end{array}$ & $\begin{array}{c}\text { Maximum } \\
\text { absolute } \\
\text { pressure } \\
\text { (bar) }\end{array}$ & $\begin{array}{c}\text { Absolute } \\
\text { Pressure } \\
\text { Difference } \\
\text { (bar) }\end{array}$ & $\begin{array}{c}\text { Water } \\
\text { temperature } \\
\text { at the upper } \\
\text { collector } \\
\left({ }^{\circ} \mathbf{C}\right)\end{array}$ & $\begin{array}{c}\text { Equivalent } \\
\text { saturation } \\
\text { temperatur } \\
\mathbf{e}\left({ }^{\circ} \mathbf{C}\right)\end{array}$ & Interpretation \\
\hline 75 & 3.25 & 3,34 & 0.09 & 76,7 & 138,2 & No risk of steam production \\
50 & 3.35 & 3,47 & 0.12 & 93,0 & 138,5 & No risk of steam production \\
25 & 3.28 & 3,48 & 0.20 & 108,6 & 138,4 & No risk of steam production \\
0 & 3.48 & 4,80 & 1.32 & 149,7 & 149,8 & Steam production \\
\hline
\end{tabular}

\section{Laboratory tests}

\subsection{Presentation}

Laboratory tests were conducted at NanoCorr, Energy \& Modeling (NCEM) Research Group, Bournemouth University, United Kingdom. The measurements of the absorber and the glass cover temperatures were performed by using a GUNT ET-202 testing unit [14] (see Fig. 10). The natural sunlight is replaced by a lighting unit with 25 halogen lamps. With this unit, a radiation of approximately $1152 \mathrm{~W} / \mathrm{m}^{2}$ is obtained. ET-202 unit includes a pump which is switched OFF because the aim in this research was to investigate the stagnation state. ET-202 unit allows for the measurements of various tilt angles of the collector. During this research, the solar collector is positioned horizontally and the obtained radiation is normal to the solar collector (highly unfavorable schedule). The fluid inside the solar collector was water.

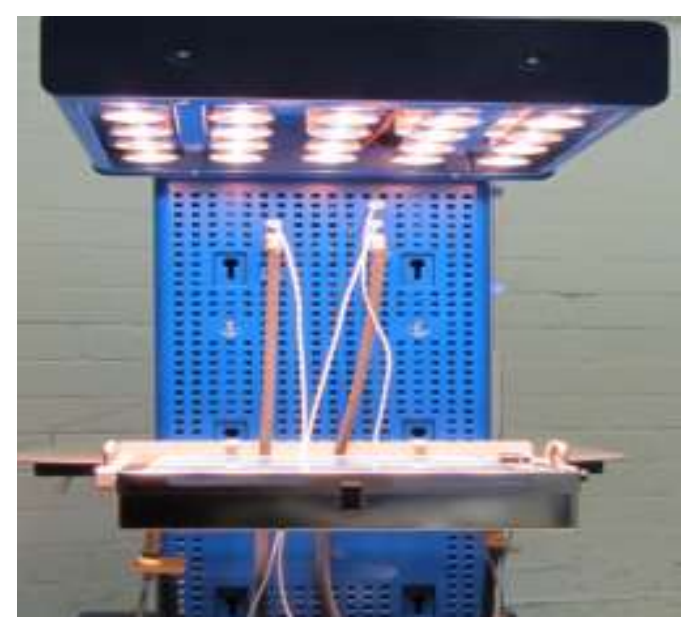

Fig.10. ET-202 laboratory testing unit [14]. 
During the tests, the solar collector $(450 \times 450 \mathrm{~mm})$ was located at a distance of $862 \mathrm{~mm}$ from the light source and all the lamps were lit. The laboratory air temperature was stable at $21^{\circ} \mathrm{C} \pm 1{ }^{\circ} \mathrm{C}$. The obtained absorber temperature was the average of three temperatures measured by LM35 temperature sensors [15]. These sensors were positioned in a diagonal pattern. LM35 temperature sensor is an analog sensor which can be operated at temperatures up to $150^{\circ} \mathrm{C}$ with a precision between $\pm 0.5^{\circ} \mathrm{C}$ and $\pm 1{ }^{\circ}$ C. The glass cover temperature was measured by using a single LM35 temperature sensor located in its center.

The absorber was coated with a non-selective black paint. The protection inserted between the glass cover and the absorber plate is an aluminum foil sheet, the reflective side facing the glass cover and the non-reflective side facing the absorber. The thermal insulation is made with high density polyurethane foam. On the sides, the insulation is $20 \mathrm{~mm}$ thick, at the back the insulation is $40 \mathrm{~mm}$ thick. The other characteristics of the solar collector used are given in Table 4.

Table 4

Characteristics of the solar collector

$\begin{array}{ll}\text { Glass cover } & \text { Size }: 380 \times 360 \times 3.2(\mathrm{~mm})-\alpha_{c}=0,12-\varepsilon_{c}=0,89-\tau_{c}=0,85 \\ & C_{c}=840 \mathrm{~J} \mathrm{~W}^{-1} \mathrm{~K}^{-1}-\rho_{c}=2500 \mathrm{~kg} \mathrm{~m}^{-3} \\ \text { Absorber } & \text { Size }: 340 \times 320 \times 0,8(\mathrm{~mm}) \\ & \text { Non selective coating } \alpha_{\mathrm{abs}}=0,9-\varepsilon_{\mathrm{abs}}=0,9 \\ & \mathrm{C}_{\mathrm{abs}}=380 \mathrm{~J} \mathrm{~W}^{-1} \mathrm{~K}^{-1}-\rho_{\mathrm{abs}}=8920 \mathrm{~kg} \mathrm{~m}^{-3} \\ & \text { Size }: 340 \times 320 \times 0,08(\mathrm{~mm})-\mathrm{C}_{\mathrm{p}}=902 \mathrm{~J} \mathrm{~W}^{-1} \mathrm{~K}^{-1}-\rho_{\mathrm{p}}=2700 \mathrm{~kg} \mathrm{~m}^{-3} \\ & \end{array}$

\subsection{Experimentation}

Three types of tests were conducted in the stagnation case, these are given as follows:

- Test without protection (see Fig. 11); in this case, the solar collector remains unprotected until the stabilization phase of the absorber temperature (about two hours) was reached.

- Test with protection (see Fig. 11); in this case, the solar collector remains protected during the test until stabilization (also two hours) had been achieved.

- Test with set temperature; at the beginning, the absorber plate is unprotected; when its temperature reaches a set temperature (called $\mathrm{T}_{\mathrm{set}}$ ), the protection is switched $\mathrm{ON}$ until the stabilization phase; three set temperatures were used as 90,100 and $110^{\circ} \mathrm{C}$.

At the beginning of the tests, all the components of the solar collector were at the laboratory temperature $\left(21^{\circ} \mathrm{C}\right)$. 

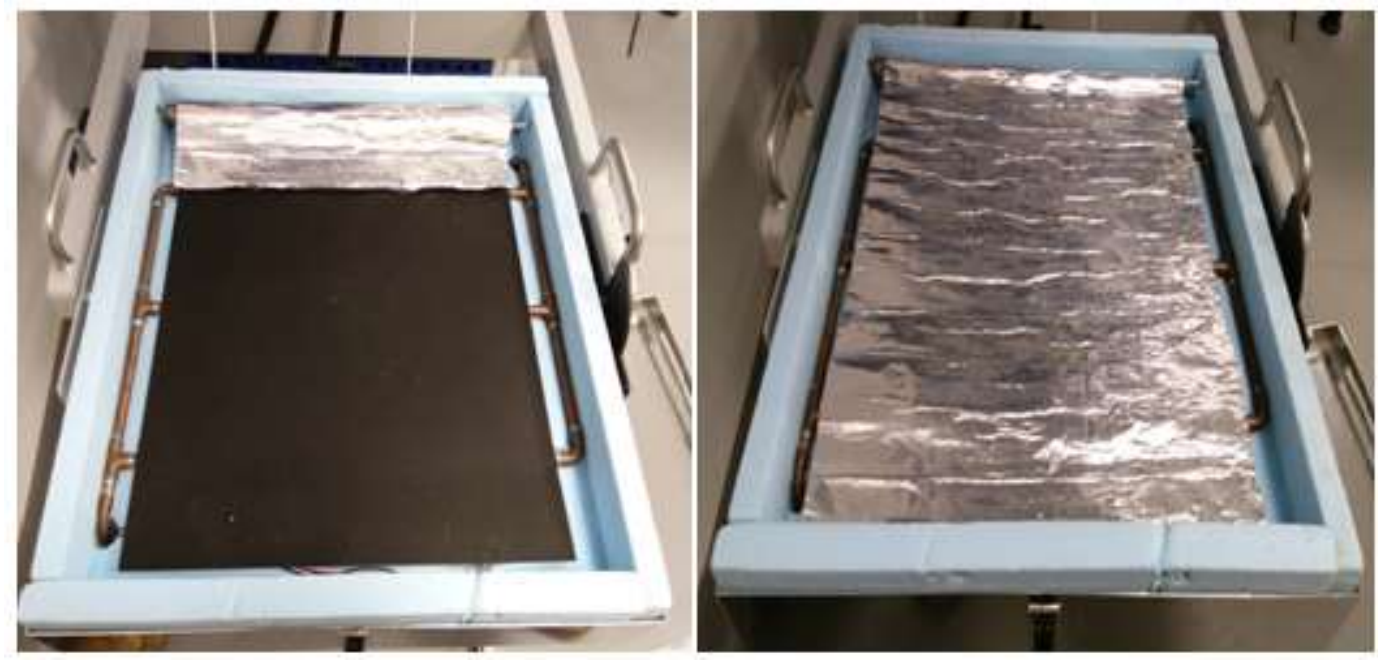

Fig.11. Left: Collector without protection - Right: Collector with full protection.

The measured values of the absorber temperature for the tested solar collector with protection and without protection are presented in Fig. 12. Without protection, the absorber temperature increases quickly during the first 15 minutes after the lighting up of the lamps. The absorber temperature reaches $100^{\circ} \mathrm{C}$ in about 17 minutes and converges to a steady-state temperature of $127^{\circ} \mathrm{C}$. In the case of an activated protection, the absorber temperature converges to a steady-state temperature of $73^{\circ} \mathrm{C}$ after more than $40 \mathrm{~min}$ of a high radiation $\left(1152 \mathrm{~W} / \mathrm{m}^{2}\right)$, which represents an extreme condition for the solar panel. The difference between the two cases is significant, i.e. $55^{\circ} \mathrm{C}$.

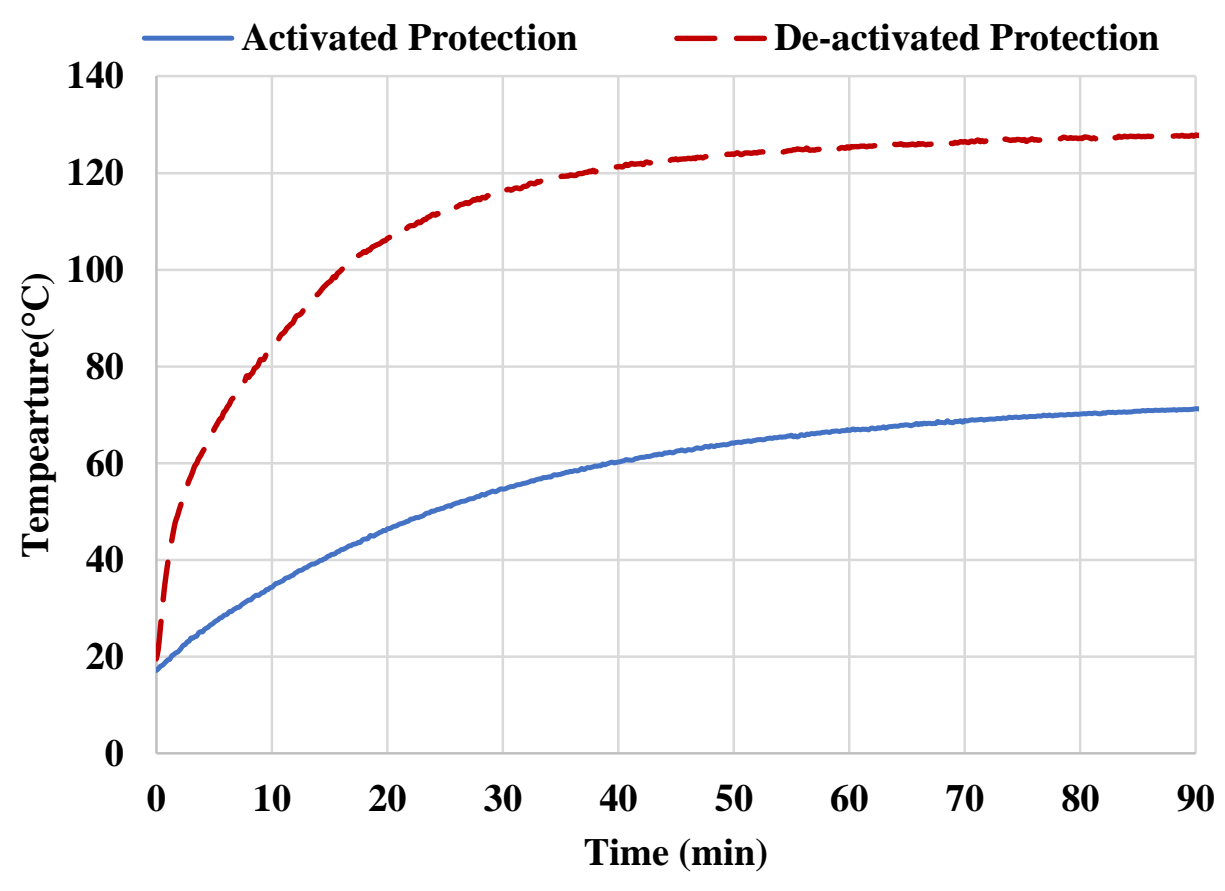

Fig.12. - Absorber temperature variations in stagnation condition of the solar collector tested in laboratory (with and without protection).

The measured values of the absorber temperature for the tested solar collector for different set temperatures are presented in Fig. 13. The absorber temperature decreases by more than $15^{\circ} \mathrm{C}$ in the 
first minutes after the activation of the protection for all cases. This rapid decrease allows keeping the absorber out of the overheating zone. The time taken to reach the stabilization phase after activation of the protection is about 15 minutes for a set temperature of $90^{\circ} \mathrm{C}$ and 45 minutes for a set temperature of $110^{\circ} \mathrm{C}$. In all cases, the absorber temperature converges to a steady-state temperature of $78^{\circ} \mathrm{C}$ after switching $\mathrm{ON}$ the protection. In case of a permanent protection, an almost equal steady-state temperature has been measured $\left(73^{\circ} \mathrm{C}\right.$, see Fig. 12$)$.

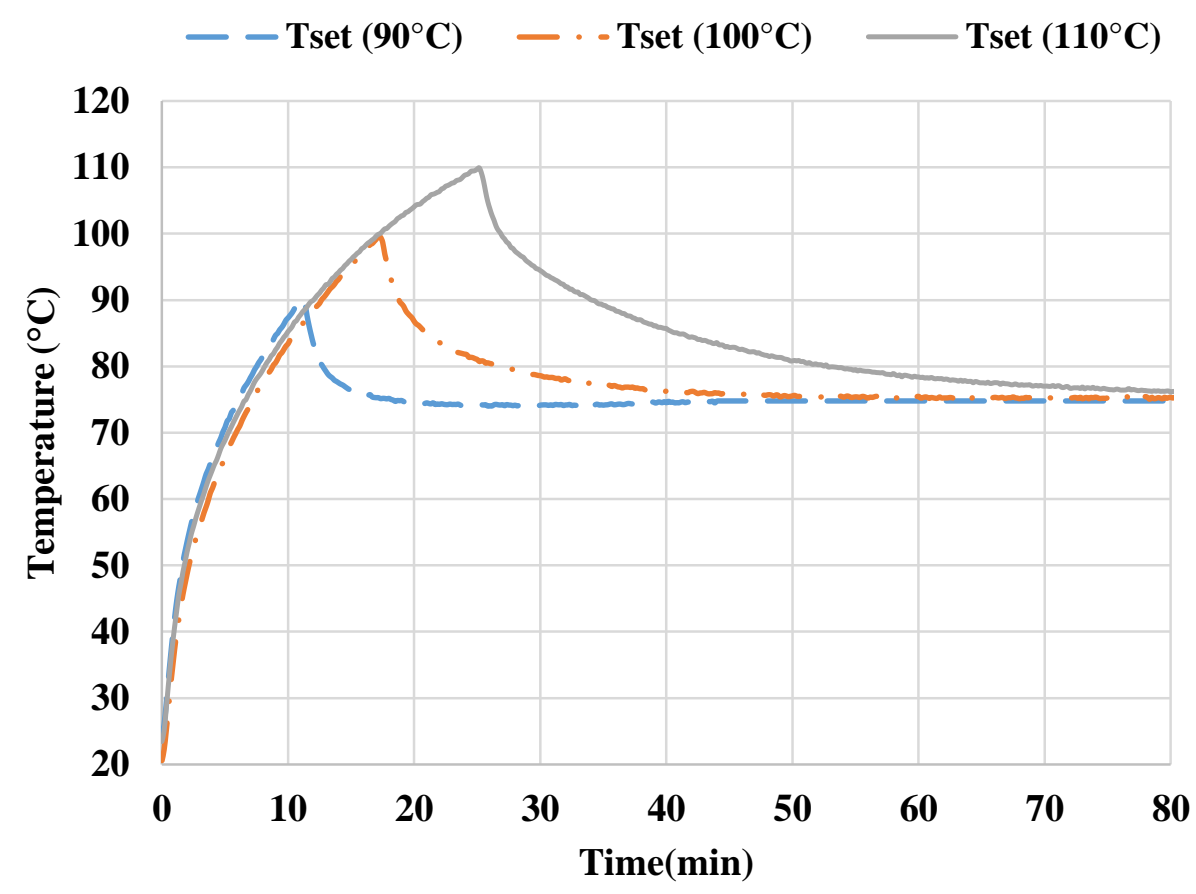

Fig.13. Laboratory test results of the absorber temperature of the solar collector protected from different set temperatures in stagnation condition.

\section{Modelling and simulations}

\subsection{Heat transfer equations}

In order to model the thermal exchanges within the tested solar collector, the following assumptions have been adopted:

- The physical characteristics of the glass cover, the absorber, and the insulation are constant.

- The air velocity at the laboratory is constant in the laboratory and is equal to $0.5 \mathrm{~m} \mathrm{~s}^{-1}$.

- The laboratory walls temperature is equal to the laboratory air temperature.

- The transmittance of the glass cover is constant.

- The physical characteristics of the fluid and of the air gap depend on their temperature.

For the unprotected solar collector, a system of four differential equations is obtained from the energy balance equations applying at the glass cover [16] (equation 1), at the absorber [16] (equation 2), at the thermal insulation (equation 3) and at the heat transfer fluid [17] (equation 4). The equation system obtained for the simulation of the solar collector without protection is as follows: 


$$
\begin{aligned}
& M_{c} C_{c} d T_{c} / d t=\alpha_{c} S_{c} G+h r_{c-s} S_{c}\left(T_{s}-T_{c}\right)+h c_{c-a m b} S_{c}\left(T_{a m b}-T_{c}\right)+h r_{c-a b s} S_{c}\left(T_{a b s}-T_{c}\right) \\
& +\mathrm{hc}_{\mathrm{c}-\mathrm{abs}} \mathrm{S}_{\mathrm{c}}\left(\mathrm{T}_{\mathrm{abs}}-\mathrm{T}_{\mathrm{c}}\right) \\
& M_{a b s} C_{a b s} d T_{a b s} / d t=\tau_{c} \alpha_{c} S_{c} G+h r_{c-a b s} S_{c}\left(T_{c}-T_{a b s}\right)+h c_{c-a b s} S_{c}\left(T_{c}-T_{a b s}\right)+\lambda_{\text {tube }} / e_{\text {tube }} S_{a b s-f}\left(T_{f}-T_{a b s}\right) \\
& +\lambda_{\text {ins }} / \mathrm{e}_{\text {ins }} S_{\text {abs-ins }}\left(T_{\text {ins }}-T_{\text {abs }}\right) \\
& M_{\text {ins }} C_{\text {ins }} d T_{\text {ins }} / d t=\lambda_{\text {ins }} / \mathrm{e}_{\text {ins }} S_{\text {abs-ins }}\left(T_{\text {abs }}-T_{\text {ins }}\right)+h c_{\text {ins-amb }} S_{\text {ins }}\left(T_{\text {amb }}-T_{\text {ins }}\right) \\
& M_{f} C_{f} d T_{f} / d t=\lambda_{\text {tube }} / e_{\text {tube }} S_{a b s-f}\left(T_{a b s}-T_{f}\right)
\end{aligned}
$$

For the protected solar collector, a system of five differential equations is obtained from the energy balance equations applying at the glass cover (equation 5), at the protection (equation 6) and at the absorber (equation 7). Equations 3 and 4 seen previously remain unchanged. We obtain the following system of equations:

$$
\begin{aligned}
M_{c} C_{c} d T_{c} / d t= & \alpha_{c} S_{c} G+\alpha_{c} \tau_{c} S_{c} G\left(1-\alpha_{p}\right)+h r_{c-a m b} S_{c}\left(T_{a m b}-T_{c}\right)+h c_{c-a m b} S_{c}\left(T_{a m b}-T_{c}\right) \\
& +h r_{c-p} S_{c}\left(T_{p}-T_{c}\right)+h c_{c-p} S_{c}\left(T_{p}-T_{c}\right) \\
M_{p} C_{p} d T_{p} / d t= & \tau_{c} \alpha_{p} S_{p} G+h r_{c-p} S_{c}\left(T_{c}-T_{p}\right)+h c_{c-p} S_{c}\left(T_{c}-T_{p}\right)+\lambda_{p} / e_{p} S_{a b s-p}\left(T_{a b s}-T_{p}\right) \\
M_{a b s} C_{a b s} d T_{a b s} / d t & =h r_{p-a b s} S_{a b s-p}\left(T_{p}-T_{a b s}\right)+\lambda_{p} / e_{p} S_{a b s-p}\left(T_{p}-T_{a b s}\right)+\lambda_{\text {tubee }} / e_{\text {tube }} S_{a b s-f}\left(T_{f}-T_{a b s}\right) \\
& +\lambda_{\text {ins }} / e_{\text {ins }} S_{\text {abs-ins }}\left(T_{\text {ins }}-T_{\text {abs }}\right)
\end{aligned}
$$

During the laboratory experiments, we have radiative heat transfer between the glass cover and the walls of the laboratory. In the equation 1, the sky temperature is replaced by the laboratory temperature $\left(21^{\circ} \mathrm{C}\right)$. The convective heat transfer coefficient between the room air and the walls is assumed to be constant and equals to $4.5 \mathrm{~W} / \mathrm{m}^{2} \mathrm{~K}$. The calculation formulae concerning the other convective heat transfer coefficients have been taken from literature [20].

The calculations were performed by using numerical models built in the MATLAB/Simulink graphical environment. To solve the systems of equations, various methods were used such as Runge Kutta of order 4 and Euler's method.

\subsection{Validation with outdoor tests}

For the validation of the numerical model, we compared the measured and calculated values of the absorber temperature (see Fig. 14). The experimental results developed on October 06th, 2018 with total and permanent protection are used. The mean absolute percentage error percentage between experimental and numerical data is $1.26 \%$. 


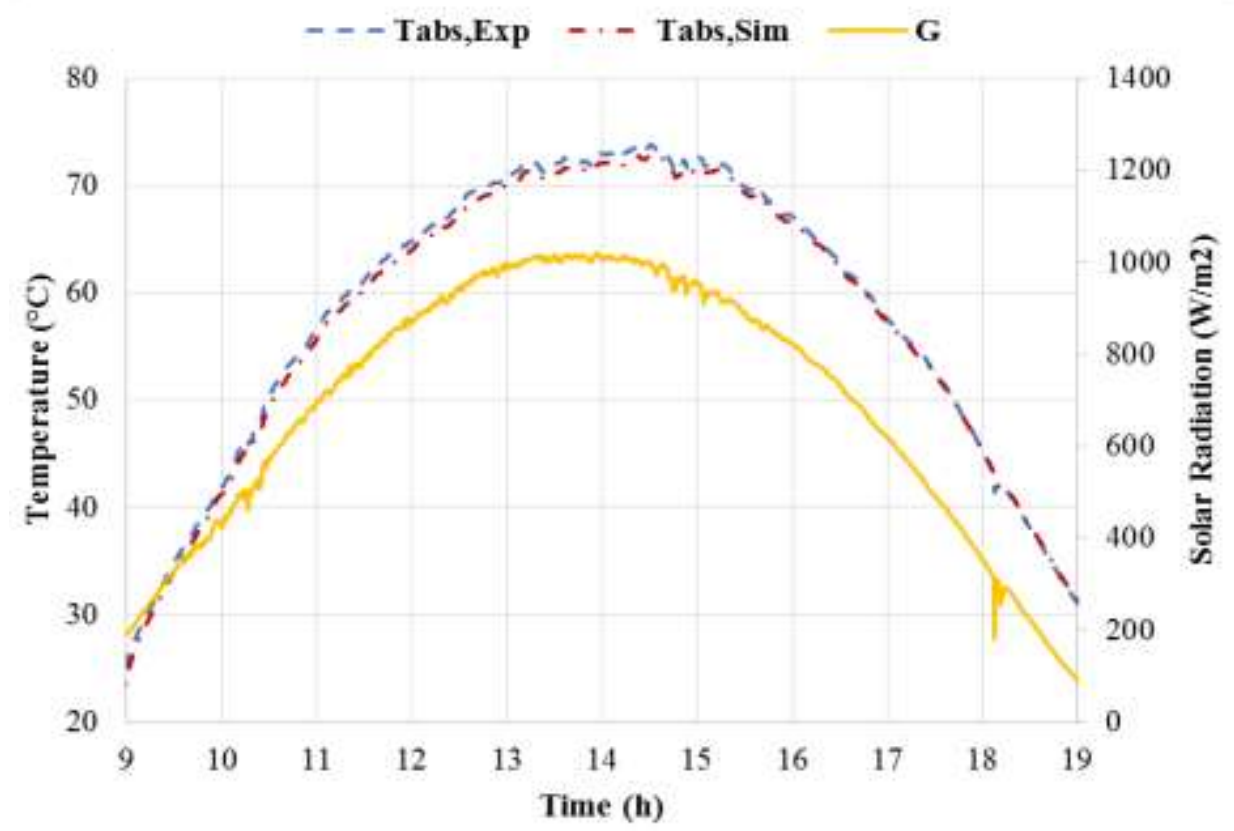

Fig.14. Absorber temperature results of outdoor test and numerical simulation in stagnation condition (collector fully protected).

\subsection{Validation with laboratory tests}

For the validation with laboratory tests, we compared the experimental results for two cases: with protection and without protection (see Fig. 15). The temperatures measured and calculated are very close and converge to the same steady-state temperatures. The mean absolute percentage error between experimental and numerical results varies between $2.76 \%$ and $6.20 \%$.

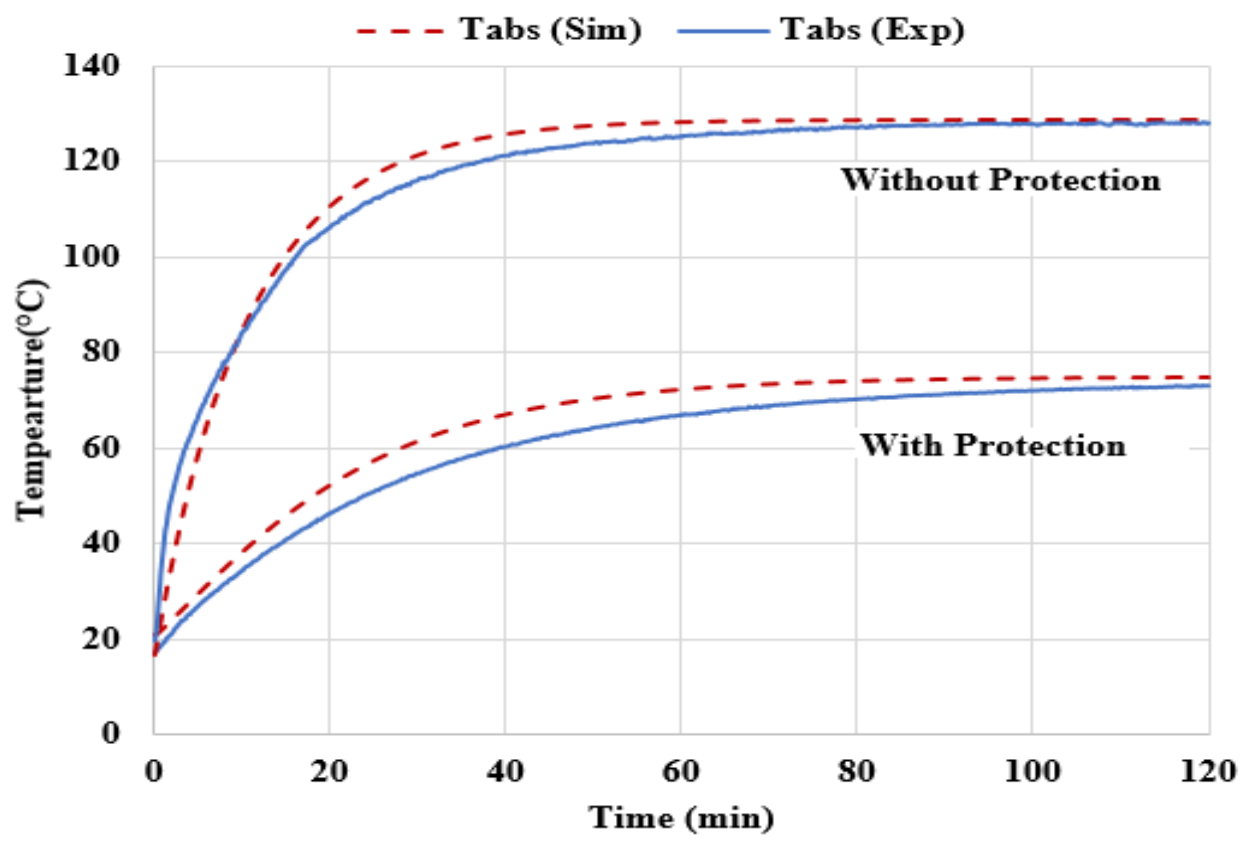

Fig.15. Absorber temperature results of laboratory test and numerical simulation in stagnation condition (with and without protection). 


\section{Conclusion}

In this work, a new solution to prevent high temperatures and steam production due to stagnation in the solar collectors has been successfully tested. The proposed solution consists of inserting a sheet of aluminium, in case of stagnation, between the absorber plate and the glass cover. This protection may be total or partial. A prototype has been manufactured and tested.

The experimental study was conducted in both laboratory and outdoor conditions. Tests with a set temperature were led: at the beginning, the absorber plate is unprotected; when its temperature reaches a set temperature, the protection is switched ON until the stabilization. Several coverage rates have been tested in field conditions.

A numerical model of the thermal behaviour of the solar collector was developed and validated with experimental results. This model takes into account only the cases of solar collectors without protection or with full protection.

The experimental tests and calculations show that the solution gives good results. Based on outdoor tests, we show that from $50 \%$ of partial protection, it is possible to avoid easily overheating. Based on laboratory tests, when the solar collector subjected to extreme solar radiation (normal radiation of $1152 \mathrm{~W} / \mathrm{m}^{2}$ ) is fully protected, the absorber temperature does not exceed $80^{\circ} \mathrm{C}$. In addition, the proposed system can be adapted to a wide range of solar thermal panels.

Based on the results obtained, the proposed solution can be considered as promising to prevent overheating of solar collectors.

During the tests, the overheating protection system has been moved manually. We have developed a preliminary design of thermal solar collector using a motorized rotary mechanism, which allows an automated movement of the protection. This device could be powered by photovoltaic cells. Future works will aim to design and implement this mechanism.

It is also remains to build a numerical model which takes into account the heat transfers in the partial protection case. Future works will take over this aspect.

\section{Acknowledgments}

The authors would like to thank the NCEM Research Group, Bournemouth University, United Kingdom, and the Department of Mechanic Engineering and Energy, University of Miguel Hernández, DMEE, UMH, Spain, for supporting experimental work, significant contributions in making this research possible and hosting the University of Sciences \& Technology Houari Boumediene (USTHB) visiting researcher.

\section{References}

[1] El Hassar. S. M. K. "Guide pour une construction éco-énergétique en Algérie", livre, 2016, Editions Universitaires Européennes, Allemagne.

[2] Gianpiero, $\mathrm{C}$ et al. "Innovation in flat solar thermal collectors: A review of the last ten years experimental results", in Renewable and Sustainable Energy Reviews, 2016, vol. 57, issue C, pp. 11411159, Elsevier Editions. 
[3] Hottel, H. C. and Woertz, B. B. "The Performance of Flat Plate Solar-Heat Collectors", in Transactions of the ASME (American Society of Mechanical Engineers), 1942, Vol. 64, pp. 64-91, USA.

[4] Beikircher, T et al. "Advanced solar flat plate collectors with full area absorber, front side film and rear side vacuum super insulation", Solar Energy Materials \& Solar Cells, Vol. 141, pp. 398-406, 2015.

[5] Giovannetti, F. "Transmittance, low emissivity glass covers for flat plate collectors Applications and performance", Vol. 104, pp. 52-59, 2014.

[6] Harrison, S. et al. "A review of strategies for the control of high-temperature stagnation in solar collectors and systems", in Energy Procedia Journal, 2012, vol.30, pp. 793-804, Elsevier Editions.

[7] Föste, S. et al. "Flat Plate Collectors with Thermochromic Absorber Coatings to Reduce Loads during Stagnation", in Energy Procedia Journal, 2016, vol. 91, pp 42-48, Elsevier Editions.

[8] Amiche, A. et al. "Flat plate collectors with thermochromic absorber coatings in the Algerian context", in proceedings book of $1^{\text {st }}$ international conference on energy and thermal engineering, April 25-28, 2017, pp. 387-391, Istanbul, Turkey.

[9] Paone, A. et al. "Thermal solar collector with VO2 absorber coating and V1-xWxO2 thermochromic glass cover Temperature matching and triggering", in Solar Energy Journal, 2014, vol. N¹10, pp. 151159, Elsevier Editions.

[10] Kessentini, H. et al. "Development of a plate collector with plastic transparent insulation and lowcost overheating protection system", in Applied Energy Journal, 2014, vol. 133, issue C, pp. 206-223, Elsevier Editions.

[11] Harrison, S.J. et al "Integral stagnation temperature control for solar collectors". In Proceedings SESCI 2004 Conference University of Waterloo, Waterloo, Canada (pp. 2-3).2004, August

[12] Shafqat, $\mathrm{H}$ and Harrison, S.J "Experimental and numerical investigations of passive air-cooling of a residential flat-plate solar collector under stagnation conditions", Solar Energy Vol. 122, pp. 10231036, 2015.

[13] Quiles, P.V., Aguilar, F.J. and Aledo, S., 2014. "Analysis of the overheating and stagnation problems of solar thermal installations" Energy Procedia, 48, pp.172-180.

[14] Boedecker, K "Experiment Instructions ET 202 - Principles of Solar Thermal Energy", Manuel, GUNT Gerätebau, Barsbüttel, august 2011, Germany.

[15] National SemiConductor, NSC (Texas Instruments), "LM35 Precision Centigrade Temperature Collectors", Technical Document, August 2016.

[16] Hamed, M et al. "Parametric sensitivity studies on the performance of a flat plate solar collector in transient behavior", in Energy Conversion and Management Journal, 2014, vol. $\mathrm{n}^{\circ}$ 78, pp. 938-947, Elsevier Editions. 
[17] Watmuff, J et al. "Solar and wind induced external coefficients for solar collectors", Revue Internationale d'Heliotechnique, 1977, vol. n², p. 56. 